\title{
Should Performance Dedicate?
}

\author{
Herman F.Selvin*
}

TN ORDER immediately to dissipate any element of suspense which may $I$ exist, let me say that, to the question posed by my title, the answer isYes. But to demonstrate that answer I shall have to indulge in a bit of historical review, in some analysis of the cases, and, most of all, in what I hope will be considered logical reasoning.

To place the question in its proper context, let me put three not uncommon situations, illustrative of the present law:

1. Assume an author of a play who, reproducing it in a few copies for sale, offers it to all who desire to buy. He neglects, however, to comply with the fairly simple requirements of the Copyright Act but does place a notice in his book that purchase of it entitles the buyer to use it only for his personal enjoyment but does not authorize him to reproduce it in copies, perform it or otherwise make any public use of it. The result of his carelessness, or perhaps, lack of legal advice, is that his work is dedicated to the public, even though he obviously had no intention of doing that, and even though he did not succeed in selling a single copy. ${ }^{1}$

2. Now assume the same author who, somewhat better advised, registers his manuscript under section 12 of the Act and thus secures the rights made available by that statute. He sedulously refrains from reproducing it in copies for sale, but he does succeed in having it performed on the stage for the benefit of all who may come. In that situation, there is no doubt that his rights are measured solely by the statute and that upon the expiration of the statutory term his work is dedicated to the public. ${ }^{2}$

3. Finally, let us take the same author who this time has received the ultimate in sound legal advice. He does not bother to register his play under the Copyright Act; nor does he reproduce it in copies for sale. But he does cause the play to be performed. Here, notwithstanding the number or extent of its public performances, he loses no rights whatever but retains for himself, his heirs and assigns, a perpetual monopoly in the work. And this is

* Member, Los Angeles Bar. Citations are intended to be illustrative rather than exhaustive.

1 White v. Kimmell, 193 F.2d 744 (9th Cir. 1952); Wagner v. Conried, 125 Fed. 798 (S.D. N.Y. 1903); Larrowe-Loisette v. O'Loughlin, 88 Fed. 896 (S.D.N.Y. 1898).

2Loew's Inc. v. Superior Court, 18 Cal.2d 419, 115 P.2d 983 (1941); Universal Film Mfg. Co. v. Copperman, 218 Fed. 577, cert. denied, 235 U.S. 704 (1914); Societe des Films v. Vitagraph Co., 251 Fed. 258 (2d Cir. 1918). For the general proposition that the statute, when invoked, is the sole measure of the author's rights, see, among others; Wheaton v. Petcrs, 8 Pet. 590 (U.S. 1834); RCA Mfg. Co.v. Whiteman, 114 F.2d 86 (2d Cir. 1940), 311 U.S. 712 (1940); Globe Newspaper Co. v. Walker, 210 U.S. 356 (1908); Caliga v. Inter-Ocean Newspaper Co., 215 U.S. 182 (1909). 
so even though as a result of its public exploitation, he becomes a multimillionaire in the process. ${ }^{3}$

One may well ask, why the statute? What does an author get from it to make up for the drastic curtailment of his monopoly which is accomplished by compliance with it? But even more basically, one may ask, why this distinction? Why this preferred position for the unpublished author as against the published one? In my opinion, and it is my thesis here this afternoon, this result has been brought about through a misconception of the early or common law on the subject, and fron a failure of analysis in the modern cases.

To establish that thesis, let me begin with some basic notions which underlie literary property law. The law of copyright reflects in striking manner a struggle between two competing policies. One the one hand there is the perfectly natural and emotionally satisfying proposition that one is entitled to the fruits of his labor; so that an author should have, as of right, the opportunity to exploit and realize upon his work, to the exclusion of others who may seek to appropriate for themselves the product of his mind.

On the other hand, there is the belief, perhaps not so strongly or widely held but with an equal claim upon the intelligent opinion of men, that monopoly, especially monopoly of learning and knowledge, cannot long be endured; and that, if the arts and sciences are to be fully utilized for the benefit of society at large, there must come a time in the not too remote future when the discoveries and inventions of one must become the property of all. ${ }^{4}$ Perhaps the best-certainly the saltiest-expression of this point of view is found in a letter from Mr. Justice Holmes to Sir Frederick Pollock, in which he said: ${ }^{5}$

I have often thought of writing about a page on copyright. The notion that such a right could exist at Common Law or be worked out by it seems to me imbecility. It would be intolerable if not limited in time and I think it would be hard to state a basis for the notion which would not lead one far afield. Non obstant the long-winded judgments in the old cases.

At any rate, it was this conflict of policies which lay at the bottom of the great dispute whether, in the absence of statute, an author had any prop-

3 Ferris v. Frohman, 223 U.S. 424 (1912); Nutt v. National Institute, 31 F.2d 236 (2d Cir. 1929) ; Uproar Co. v. National Broadcasting Co., 8 F. Supp. 358 (D. Mass. 1934), modified, 81 F.2d 373 (1st Cir. 1936); McCarthy \& Fisher v. White, 259 Fed. 364 (S.D. N.Y.1919); Crowe v. Aiken, 6 Fed. Cas. 905, No. 3441 (C.C.N.D. Ill. 1870); Boucicault v. Hart, 3 Fed. Cas. 983, No 1692 (C.C.S.D.N.Y. 1875) ; Roberts v. Myers, 20 Fed. Cas. 898, No. 11906 (C.C. D. Mass. 1860)

4 The classic statement of this proposition is probably that of Lord Mansfield in Sayre v. Moore, 1 East. 361, quoted in Eichel v. Marcin, 241 Fed. 404, 410 (S.D.N.Y. 1913).

- 1 Holmes-Poliock Letrers, 53 (Howe ed. 1941). The urge to write "about a page on copyright" was gratified in the Justice's concurring opinion in White-Smith Mnsic Co. v. Apollo Co., 209 U.S. 1, 19 (1908). 
erty in his work which survived its first publication or circulation to the public. That dispute was never clearly settled until the famous decision of the House of Lords in Donaldson v. Becket ${ }^{6}$ in 1774. By that time the first great copyright statute was already on the books in England. ${ }^{7}$ So the question was not alone what were an author's rights at common law-but also, to what extent, if at all, had those rights been changed by the statute? The Lords decided that while a perpetual and exclusive right in such works existed at common law, the right had been taken away and superseded by the Statute of 8 Anne which secured to authors, for a limited term, the exclusive right to print, publish and republish their works. Obviouslythough it did not seem so obvious to a substantial nninority of the judges

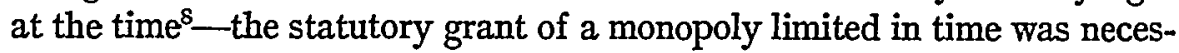
sarily inconsistent with any notion of a coexisting perpetual right to such a monopoly in the same work. There was no reason for the statute if at common law the right which it sought to secure already existed and continued forever. ${ }^{9}$

The effect of that decision, coupled with 8 Anne, therefore, was to stake out the middle gronnd between the two policy extremes. Perpetual monopoly was avoided; but so was denial to the author of a reasonable opportunity to realize upon his work. He was given a monopoly to provide him with that opportunity, but it was limited $\mathrm{m}$ time in order to advance learning and knowledge in general.

In this country the resolution of this fundamental difference in philosophy was brought about in pretty much the same way. The clearest indication of a rejection of the concept of perpetual monopoly, while preserving an opportunity to exploit, was given in the Constitution, which, as you will recall, empowers the Congress to enact laws securing to authors and inventors the exclusive right to their writings and discoveries-but only for limited times. ${ }^{10}$ Judicially, the question was settled here by the United States Supreme Court in Wheaton v. Peters ${ }^{11}$ holding that the rights of an author were referrable solely to the statute, which created a new right and superseded any that might have existed at common law. In point of fact, although it was not necessary so to decide, the case gives out a very strong intimation that in the opinion of that court at that time, there was not in

64 Burr. 2408, 2 Broun 129, 1 Eng. R. 837, 98 Eng. R. 257 (1774).

78 ANNE, c. 19.

8 Of the eleven judges who participated in Donaldson v. Becket, five were of the opinion that the common law right had not been taken away by the statute.

9 Compare the cases cited note 2 supra.

10 U.S. Const. Art. I, §8.

118 Pet. 590 (U.S. 1834). 
this country, any exclusive right in an author which, in the absence of statute, would survive publication. ${ }^{12}$

Having thus resolved the policy debate in favor of a limited rather than a perpetual monopoly, and in favor of the statutory supersession of any common law right which miglit otherwise lave existed, the next step became inevitable. It was to hold that upon publication without compliance with the statute or upon expiration of the statutory term when there had been compliance, the author's monopoly came to an end and the unrestricted right of the public began. And, of course, at least so far as concerns works which are publicly circulated by distribution of copies rather than by presentation or performance, that is and should be the law. ${ }^{13}$

However, neither Donaldson nor Wheaton completely settled the ancient argument. The early copyright statutes, lere as well as in England, were exactly that-they secured to an author only the right to primt, publish and republish his work, that is, to reproduce it in copies. ${ }^{14}$ They did not secure to him the exclusive or any right to perform or represent it in public. Even when, at a later date, play-or performance-right was secured, it was only in respect of printed or published works, and not in respect of those which were not so reproduced. ${ }^{15}$ Yet, a good deal of what for convenience is called "literary property" is never reproduced in copies for sale but is circulated to the public and its composers realize from it, only by public performance or representation. Dramas, sermons and lectures are examples which readily come to mind.

So there recurred the old dispute whether, in the absense of a statute securing the right of representation, the author had an exclusive right so to do which survived his first public utilization of it-and once again we see in the decisions the struggle between the two competing policies to which I have referred. In this instance, lowever, the conflict was differently resolved, as the examples already given indicate. ${ }^{16}$ But the question still re-

12 For example, the folowing appears at 8 Pet. 660:

That congress, in passing the act of 1790 , did not legislate in reference to existing rights, appears clear, from the provision that the author, \&c., "shall have the sole right and liherty of printing," \&c. Now if this exclusive right existed at common law, and congress were ahout to adopt legislative provisions for its protection, would they have used this language? Could they have deemed it necessary to vest a right already vested. Such a presuinption is refuted by the words above quoted, and their force is not lessened by any other part of the act. Congress, then, by this act, instead of sanctioning an existing right, as contended for, created it. This seems to be the clear import of the law, connected with the circumstances under which it was enacted.

From these considerations it would seem, that if the right of the complainants can be sustained, it must be sustained under the acts of Congress ....

13 Cases cited note 2 supra; Fashion Originators Guild v. Federal Trade Com'n., 114 F.2d 80 (2d Cir. 1940), af'd, 312 U.S. 457 (1941).

14 I STAT. 124 (1790); 8 ANNE, c. 19.

15 Ferris v. Frohman, 223 U.S. 424 (1912).

10 Cases cited note 3 supra. 
mains-at least for those who may be concerned with a revision of the copyright statutes-was it correctly resolved? If it was good policy in the case of multiple-copy works to limit the author's monopoly, is it not equally good policy to do so in the case of the represented work? Whatever may be thought the correct answer when no statutory provision is made for securing performance rights in an unpublished work, when there is made available statutory protection of that right for a limited term, as has been the case in this country since $1909^{17}$ and in England since the statute of 5 and 6 Victoria, ${ }^{18}$ should not the answer as to the existence and persistence of a perpetual common law right have been the same as it was in the case of books?

The logic of the situation seems to me inescapably to call for an affirmative answer to that question. It has not seemed so inescapable to the courts -for, in the United States at least, the rule now seems to be that performance or representation of an unpublished work, even though general, indiscriminate and unrestricted, is not a dedication of the perpetual common law right. ${ }^{19}$

I have intimated uny opmion that this result has come about from a misconception of the early law and from a failure of analysis in the modern cases. Let ine demonstrate that conclusion, if I can. For that purpose, we need not for the moment go back beyond 1912 for it is with a decision of the United States Supreme Court in that year, Ferris v. Frohman, ${ }^{20}$ that the modern law begins, although it was thought by that court to have its roots in much more ancient decisions. ${ }^{21}$ The Ferris case, decided in 1912, arose on facts occurring before 1909-in other words, before the Copyright Act of that year which, for the first time in this country, secured copyright in so-called unpublished works. That fact has apparently not been noted by later judges who followed Ferris-or if noted, has not been appreciated. For the holding in Ferris, that representation or performance did not dedicate, was to a considerable, if not sole, extent impelled by the fact that an author of a performable work, not reproduced in copies for sale, at the time there material, could not have secured his right under the statute; from which fact the court drew the conclusion that the authors' common law rights had not been superseded or taken away. ${ }^{22}$ That the result there reached was brought about for the reason which I have given, is readily discernible from the opinion of $\mathrm{Mr}$. Justice Hughes read at large. His precise

1717 U.S.C. $\& 12$ (1909).

185 and 6 VICTORIA, c. 45.

19 Cases cited note 3 supra.

20223 U.S. 424 (1912).

21 The latest case cited to the proposition that performance does not dedicate had been decided in 1870 .

22 See, e.g., Ferris v. Frohman, 223 U.S. 424, 433 (1912). 
holding was that, in the absence of statute, performance did not dedicate. ${ }^{23}$ He pointed out that since 5 and 6 Victoria, opinion in England was that Donaldson v. Becket, insofar as it held the common law superseded, would be logically extended to the case of playright-i.e., that the statutory grant of playright for a limited term would be held a destruction of any common law right in that regard-and accordingly he assumed that to be the law of England. ${ }^{24}$ Again, in denying that performance in England, although a publication and a consequent destruction of the common law right there, had that effect here, he noted that there was no statute in this country which, like 5 and 6 Victoria, enabled an author to secure play-or performance-right in an unpublished work. ${ }^{25}$ That being so, and since Justice Hughes thought there was a perpetual right at common law, the conclusion necessarily followed that that right had not been supplanted or destroyed in this country and consequently, that performance could not be a dedication. $^{26}$

Now, whatever may be said for that reasoning in the statutory context in which it was indulged, it is manifestly mappropriate to a case arising under the 1909 Act. For under that Act the unpublished author may secure a copyright, or more accurately, a play —or performance-right, ${ }^{27}$ and that being so, exactly the reasoming which impelled the courts in Wheaton $v$. Peters and Donaldson v. Becket to hold that any common law right in a published work had been superseded, should have impelled the courts to hold that the analogous common-law right of perpetual, exclusive performance had been superseded by the statutory right. With one exception, however, courts since Ferris v. Frohman, have done no more than to quote Mr. Justice Hughes' holding that performance does not dedicate and have applied it indiscriminately without apparent appreciation, certainly without discussion, of the effect upon that rule of the legislation of 1909.

The one exception is Nutt v. National Institute ${ }^{28}$ in the Second Circuit. There it was evidently argued that the 1909 Act had changed the rule of Ferris v. Frohman. The court rejected the argument summarily, relying on section 2 of the Act for its conclusion in that regard. Section 2, in language, saves any rights in unpublished works which may exist at common law. If, as in the concluding portion of this talk I shall contend, the rights of exclusive performance, even at common law, did not survive its first unre-

23 "The public representation of a dramatic composition, not printed and published, does not deprive the owner of his common law right, save by operation of statute . . ." Id. at 435 (italics added).

24 Id. at 432.

25 Id. at 434.

26 Id. at $434-435$.

${ }^{27}$ See note 17 supra.

2831 F.2d 236 (2d Cir. 1929). 
stricted utilization, that line of reasoning cannot be accepted. Furthermore, if, as has been held (though not without dissent), a "published" work is merely one which has been communicated to the public, ${ }^{29}$ then a publicly performed play is no longer an "unpublished" work and, therefore, no longer within the protective embrace of section 2 . Be that as it may, another and fundaniental difficulty with the reasoning in Nutt v. National Institute is that it proves too much. It has been held that section 2 nerely saves to an author such rights as he has until he avails himself of the statutory protection..$^{30}$ But if that is all that it does, then the necessary conclusion from $N u t t$ is that even one who reproduces his work in copies for sale, but does not secure statutory copyright, should still be left with his supposed perpetual common-law right. Yet, as we all know, that is not true. Publication or circulation of copies, without statutory compliance, dedicates his work-and hardly anyone would now argue that it should not. Parenthetically, it may be observed that it was the presence of a similar proviso in the Statute of 8 Anne which provided most of the support for the argument, which did not prevail in Donaldson v. Becket, that the statute had not superseded the common law right. ${ }^{31}$ And, of course, the argument should not have prevailed. Unless a copyright statute, securing exclusive rights for a limited term only, is to be made a useless enactment and, $m$ fact, transformed into a penalty against the author of a work which is protected under it, it must be held that public utilization of a right which the statute secures has the same effect upon the common law monopopy, if any, as would come about from compliance-in other words, that when an author exploits his composition in a way in which he could be secured by the statute, his monopoly is at an end except to the extent provided by, and upon the conditions laid down in, the statute.

I think this analysis is supported by a decision of the most experienced copyright judge in America, Learned Hand-a decision in which it was ruled that publication, even of a work which could not be protected under the statute, accomplished its transfer into the public demesne. In the course of that decision-Fashion Originators Guild v. Federal Trade Com. ${ }^{32}$ Judge Hand pointed out that notwithstanding the determination in Donaldson v. Becket that a perpetual right to multiply copies existed at common law, there was considerable basis for believing that it would not have been carried out in all of its logical implications in that regard even in England. He noted that in any event the logic of that decision was overcome by the

${ }^{20}$ Marx v. U.S., 96 F.2d 204, 206 (9th Cir. 1938).

80 Photo-Drama etc. Co. v. Social Uplift, 220 Fed. 448, 450 (2d Cir. 1915).

81 The opinions of the judges in Donaldson v. Becket are not reported, only their votes being recorded. In the King's Bench, however, the opinions were extensively reported sub. nom. Millarv. Taylor, 4 Burr. 2303, 98 Eng. R. 201 (1769).

82114 F.2d 80 (2d Cir. 1940). 
practical absurdity of the result-and that it could not be supposed that the Congress intended to place the author whose works could be protected under the Act at such a disadvantage vis-a-vis an author whose works could not be-giving to one only a limited monopoly, while leaving to the other a perpetual one. And in this connection he adverted to an obvious, but all too frequently overlooked, fact that the policy in favor of limited monopoly, imported by the United States Constitution, was inconsistent with any assumption "that an author-notwithstanding publication and full enjoyment of his 'common law property'-miglit maintain his monopoly for 'unlimited Times.' . . . "33 I also draw some comfort in this regard from two California decisions. One of these is Loew's Inc. v. Superior Court, ${ }^{34}$ in which our Supreme Court fully accepted the proposition that, at least insofar as a work is protected under the statute, there is accomplished a dedication of, or a substitution for, the common law right. The other is Richardson v. Hislop, ${ }^{35}$ in which concurrence is expressed in the principle "that it is only through the provisions of the copyright law that the work of authors, designers and inventors can be protected as their individual property."

That brings me, then, to the next and concluding subdivision of my subject. I hope it is apparent, by now, that regardless of the soundness-or want of it - of the argument which $I$ have made, there is no basis whatever for the rule that performance does not dedicate, unless that was the rule at common law. For the major premise of all reasoning on the subject is the proposition that there is a perpetual right at common law whicl, unless taken away by statute, persists after publication or performance. If that premise is wrong, the rule based upon it is equally erroneous.

In Ferris v. Frohman, Mr. Justice Hughes, without qualification and without suggestion that there might be any doubt about the matter, said: ${ }^{36}$

The public representation of a dramatic composition, not printed and published, does not deprive the owner of his common law right, save by operation of statute. At common law the public performance of the play is not an abandonment of it to public use ....

citing six decisions from England and this country. ${ }^{37}$ On the other hand, our own Supreme Court, througll Mr. Justice Shenk, in Loew's Inc. v. Superior Court, stated that the decisions on this point were in conflict. ${ }^{38}$ Judge Shenk was inuch more nearly right than was Justice Hughes.

33 Id. at 83 .

3418 Cal.2d 419, 115 P.2d 983 (1941).

35 109 Cal. App. 440, 452, 293 Pac. 168, 173 (1930).

38223 U.S. 424,435 (1912).

37 Macklin v. Richardson, Ambler 694, 27 Eng. R. 451 (1770); Morris v. Kelly, 1 Jac. \& W. 481, 37 Eng. R. 451 (1820) ; Boucicault v. Fox, 5 Blatch. 87; Crowe v. Aiken, 6 Fed. Cas. 905, No. 3441 (C.C.N.D. III. 1870) ; Palmer v. DeWitt, 47 N.Y. 532, 7 Am. Rep. 480 (1872); Tompkins v. Halleck, 133 Mass 32 (1882).

3818 Cal.2d 419, 423, 115 P.2d 983 (1941). 
Of the six decisions cited by Mr. Justice Hughes, not more than two can be said to have decided squarely that public, unrestricted performance of an unpublished play did not dedicate. ${ }^{3 \theta}$ The others held only that such performance did not dedicate the right to reproduce the work in copies, which is quite a different thing from saying that it did not dedicate the performance right; and in some of these decisions it was at least intimated that a performance of the play by another, from memory of the author's performance, was no infringement of the latter's rights. It cannot fairly be said that these six decisions support in its full scope the broad generalization upon which Mr. Justice Hughes relied.

On the other hand, among a considerable number of decisions which might have been but were not cited in Ferris, there are several which not only do not support the Hughes pronouncement, but actually destroy it. For example, there are cases such as Keene v. Wheatley, ${ }^{40}$ decided in the U.S. Circuit Court in 1861 in which, after an extended and brilliant review of the philosophical and decisional bases of the law, it was concluded that any work circulated among the public could be availed of to the extent permitted by the means employed by the author to disseminate knowledge of its contents-from which it followed that in the case of a performed play or a picture or the like, anyone who could, might reproduce it from memory and himself perform or represent it.

So, too, there are cases in England, such as Jefferys v. Boosey, ${ }^{41}$ Abernethy v. Hutchinson ${ }^{42}$ and Caird v. Sime, ${ }^{43}$ holding that in the absence of some contractual or trust obligation to refrain, the auditors of a public lecture might thereafter use or reproduce it for their own purposes. Similarly, public exhibition of a painting will accomplish a dedication, unless the exhibition is so hedged about with restrictions against copying as to lead to a finding of limited, rather than general, publication. ${ }^{44}$

Cases of this sort certainly do not square with any unqualified dictum to the effect that public representation does not dedicate. Nor, up to the time that the 1909 Act was adopted, was there any generally accepted belief

39 Crowe v. Aiken, 6 Fed. Cas. 905, No. 3441 (C.C.N.D. Ml. 1870) ; Tompkins v. Halleck,

133 Mass. 32 (1882).

4014 Fed. Cas. 180 , No. 7644 (C.C.E.D. Pa. 1861).

414 H.L.C. 681 , 10 Eng. R. 681 (1854).

423 L.J. Ch. (O.S.) 209, 1 Hall \& Twells, 28, 47 Eng. R. 1313 (1825).

4312 App. Cas. 326 (1887).

44 Pierce etc. Mfg. Co.v. Werckmeister, 72 Fed. 54 (Ist Cir. 1896) ; Werckmeister v. American Litho. Co., 117 Fed. 360 (S.D.N.Y.1902); 126 Fed. 244 (S.D.N.Y.1903), 134 Fed. 321 (2d Cir. 1904); American Tobacco Co. v. Werckmeister, 207 U.S. 284 (1907). Analogous decisions are: Shapiro, Bernstein \& Co. v. Miracle Record Co., 91 F. Supp. 473 (N.D. Ill. 1950); Wright v. Eisle, 86 App. Div. 356, 83 N.X. Supp. 887 (1903); Vernon Abstract Co. v. Waggoner Title Co., 49 Tex. Civ. App. 144, 107 S.W. 919 (1908) ; Kurfiss v. Cowherd, 233 Mo. App. 397, 121 S.W.2d 282 (1938). 
that the common law fully and always protected the dramatist or lecturer whose work had been publicly and unresrictedly performed. The 1909 Act - section 12 , originally section 11 -as we have seen, secures an author's rights in so-called unpublished works. The Senate and House committees which had the bill in charge justified the inclusion of that section upon the ground the common law did not adequately protect an author in such cases. They adverted expressly to the instance of a performed play being reproduced from memory or even from a stenographic transcription of its public representation, as an example of what they had in mind. Accordingly, they concluded:

If an author desires to keep his dramatic work in unpublished form and give public representations thereof only, this right should be publicly secured to him by law. We have endeavored so to frame this paragraph as to amply secure him in these rights. ${ }^{45}$

The Committee which issued this report had held extensive hearings-and before them appeared the leaders of the copyright bar and the most active lay advocates of full protection of an author's property in his work. That they, and the Committee, felt the need of statutory creation of a right of exclusive performance, is to me a pretty strong indication that even as late as 1909 it was not generally believed that such a right existed at common law.

Some further indication that Mr. Justice Hughes' generalization did not accurately represent the accepted view of the common law is furnished by section 983 of the California Civil Code. As originally enacted in 1872 and for many years thereafter, it provided that:

If an owner of a product of the mind intentionally makes it public, a copy or reproduction may be made public by any person, without responsibility to the owner, so far as the law of this state is concerned.

Note particularly, that the Code framers did not say "if the work is reproduced in copies for sale," for that phrasing would have made it clear that the author's right survived performance. What they did say was "intentionally makes it public" which is plainly broad enough to include publication by representation or performance. Since, in most basic respects, the Civil Code was an attempt to codify the common law, section 983 to my mind offers striking evidence of the accepted view, as of 1872 at any rate. And in Stanley v. Columbia Broadcasting System, ${ }^{46}$ our Supreme Court-properly as at least one Justice said in a later case ${ }^{4 \pi}$ - acquiesced in a conces-

45 H. R. Rep. No. 2222, 60th Cong., 2d Sess. 22 (1907-1908).

4035 Cal.2d 653, 660-661, 221 P.2d 73, 77-78 (1950).

47 Traynor, $J$., concurring in Kurlan v. Columbia Broadcasting System, 40 Cal.2d 799, 256 P.2d 962 (1953). 
sion of counsel, of whom, I hasten to add, I was not one, that section 983 in its original form was declaratory of the common law.

Having thus touched incidentally upon the law of California, a few moments may be spent in exploring the present state of that law. In cases arising under section 983 as it stood down to 1947, there can be little doubt that a public, unrestricted performance or representation of an otherwise unpublished work, effected a dedication. Precisely to that effect is a wellconsidered opinion of Judge Stevens in Blanc v. Lantz, ${ }^{48}$ a reported decision of the Los Angeles Superior Court; and the intimations are strong in Loew's Inc. v. Superior Court, Stanley v. Columbia Broadcasting System, and the Kurlan $n^{49}$ and Weitzenkorn ${ }^{50}$ cases decided only a few months ago, that this would be the result. Certainly, the language of the statute leaves little room for argument to the contrary. In 1947, however, the section, along with others, was recast so as to read: ${ }^{51}$

If the owner of a composition in letters or art publishes it the same may be used in any manner by any person, without responsibility to the owner, insofar as the law of this State is concerned.

The effect of that change has yet to be determined. In a recent concurring opinion, Mr. Justice Traynor has indicated his view that the 1947 changes were desigued only to make it clear that the property right in literary property depended on whether or not it had been published; not on whether the tangible embodiment of the work remained in the author's possession, and that it did not otherwise change the meaning of the sections. ${ }^{62}$ It may be, however, that the answer to our question will depend upon the meaning to be given the word "publish." Does it mean the same as "intentionally make public" or was it desigued to confine the situation to "publish" in the narrow sense of "reproduction of copies"? Cases in other jurisdictions will lend support to either view, with I should say a substantial majority in favor of the view that in copyright law "publish" means "make public" or "communicate to the pubhic." ${ }^{13}$ While I have little doubt that my personal belief may be deduced from what I have already said and, I may add, was fully put before the Supreme Court in Loew's Inc. v. Superior Court, it is perhaps the wiser policy in the present circumstances to refrain from any further or defimitive expression of opinion on this question.

The upshot of this discussion, then, is simply this. While the rule seems settled-in the Federal courts at least-that performance does not dedi-

4883 U.S. P.Q. 937.

49 Kurlan v. Columbia Broadcasting System, 40 Cal.2d 799, 256 P.2d 962 (1953).

50 Weitzenkorn v. Lesser, 40 Cal.2d 778, 256 P.2d 947 (1953).

51 Cal. Stats. 1947, c. 1107, p. 2546.

52 Kurlan v. Columbia Broadcasting System, 40 Cal.2d 799, 256 P.2d 962 (1953).

53 Marx v. U.S., 96 F.2d 204, 206 (9th Cir. 1938). 
cate, I believe that rule to be wrong. Wrong because it is opposed to the policy to which the Constitution of this country has committed us; because it makes out of the Copyright Act, insofar as it provides for copyright of works not reproduced in copies for sale, not only a useless statute but a positive detriment to the author who avails himself of its provisions; wrong because it proceeds on a premise as to the common law which cannot be fully accepted as an accurate statement of that law.

It is, I suppose, too late to hope for change by judicial decision, at least in those jurisdictions where the present view has been received. Rights of great value, no doubt, have vested in reliance on what it has been supposed is the law. To mention only one instance, it is, I understand, the rare exception rather than the rule, to copyright the many dramatic plays and other works performed and represented over radio, but not otherwise published. To defeat the expectations which decisions such as Ferris v. Frohman have built up in that regard, it could be argued, would be too much to expect of a court-although in that connection, it is a question how far a California court, for instance, would be precluded from adopting its own rule on the subject by the fact that property in this state has been acquired in reliance on the decisions of other jurisdictions. ${ }^{54}$ In any event, in those jurisdictions in which the Ferris rule has been followed, it is not likely that the courts will repent. Of course, they could change the rule prospectively, enforcing it in its old tenor only in those cases where the literary property involved had been acquired or created in reliance on it. There is precedent for that kind of approach to a change in case law; ${ }^{55}$ but to take it involves a more explicit admission of the fact that courts sometimes inust and do legislate than most judges are willing to make. Rehef, or change, if it comes at all, will probably have to come from Congress. Those who for some time have been and are now engaged in seeking modernization and revision of the Copyright Act might do worse than to give some consideration to the subject with which I am now done.

54 Chambers v. Mumford, 187 Cal. 228, 232, 201 Pac. 588, 590 (1921); Bank of Italy v. Bentley, 217 CaI. 644, 652-653, 20 P.2d 940, 943-944 (1933), cert. denied, 290 U.S. 659 (1933). 60 The cases are collected in an Annotation, 85 A.L.R. 262 (1933). 